\title{
QUILOMBOS ON SÃO TOMÉ, OR IN SEARCH OF ORIGINAL SOURCES
}

\author{
Jan Vansina \\ University of Wisconsin-Madison
}

A few years ago I was reading a doctoral dissertation concerned with the history of São Tomé, when one particular word fairly leapt off the page. It came at the end of an episode telling how a particular ethnic group on the island today had arrived there. The story told how a number of Angolan slaves, later called Angolares, ${ }^{1}$ were shipwrecked just off the coast of São Tomé in 1544 (or 1554), "though (of course) no accurate date or account of the circumstances exists." The survivors swam to shore and moved into the bush "building there a series of small villages called Quilombos." It was that word, "Quilombos," that made me jump to attention, for it is a very important word in Angolan history and a written record of it from either 1544 or 1554 would be sixty to seventy years earlier than the hitherto first-known mention of the word. ${ }^{3}$ If it were true, profound revisions to the accepted political history in Angola during the sixteenth century would be called for, and even the chronology of the onset of the Lunda (Ruund) kingdom far inland would have to be revised. ${ }^{4}$

Given these stakes, it is not surprising that, once I found some free time, I began to search for the original sixteenth-century document in which this magic word first appeared. This note describes the wholly unexpected leaps and bounds encountered on this search, something with which other researchers are also familiar.

In Angola "quilombo" designated both the temporary settlement of the armed bands and the social organization of the celebrated Jaga, those armed bands of nomads who ravaged Angolan lands west of the Kwango from at least the 1590s. Both were described by a witness who lived among them from 1601 to 1603 , but he did not tell us its African name. ${ }^{5}$ The first known appearance of the word "quilombo" as such is in a letter from governor João Correia de Sousa to a friend in June $1622 .{ }^{6}$ As used there, the term refers to the warcamp of African allies (very likely Jaga) and was then obviously familiar enough to the Portuguese in Angola to require no explanation.

In contrast, four years earlier (July 1618) another governor, Manuel Cerveira Pereira, writing from Benguela to the king of Portugal about a local Jaga band, still referred to their camp as "povoassão" (settlement) rather than "quilombo." The term was then probably not yet commonly used among the Portuguese, a suspicion that is confirmed by the copy of an earlier letter (August 1617) from the governor of Angola to the king of Portugal. In it he related that the self-same Manuel Cerveira Pereira in Benguela had allied himself with a "Columbo de Jagas," "a band of Jaga," i.e., a quilombo. Clearly the copyist was not yet familiar with the term, but the governor was. One may therefore assert with a certain confidence that the word "quilombo" History in Africa 23 (1996), 453-459. 
entered the Portuguese vocabulary in Angola around or just after 1615, i.e., at the very time that the local governors began to conclude alliances with the Jaga. All this makes the occurrence of the term at least sixty years earlier and in São Tomé distinctly intriguing.

The obvious next step was to track down the document to which Garfield seemed to refer and to pursue its exact wording. In his footnotes 56 and 57 of his "History," he referred to the local writer and historian Francisco Tenreiro's book, which was not easily available to me when I began this inquiry." However, Tenreiro had also published an article about a description of the island of São Tomé in the sixteenth century, in which he mentioned that the Angolares had been shipwrecked in 1544 and had quilombos by mid-century. ${ }^{10}$ As the whole article was a presentation of a relation by an anonymous Portuguese pilot, the only reference to a sixteenth-century text I had met so far, I wondered if perhaps the magic word occurred in that text, despite Tenreiro's remark that the pilot made no reference at all to the Angolares themselves. ${ }^{11}$ So I began to look for that.

Both Tenreiro and Garfield referred to an edition of this text in Portuguese, Garfield (both in the thesis and the book) to an undated (probably 1930s) edition in a popular series; Tenreiro-nominally at least-to an older edition of 1821. Tenreiro also claimed that the original was in Latin. ${ }^{12}$ It was easily found that the original Portuguese edition appeared in the Collecçáo de noticias para a historia e geografia das nações ultramarinas, part $2 / 2$, published by the Royal Academy of Sciences in Lisbon in 1812-not 1821. The piece was entitled "Navegação de Lisboa á ilha de $\mathbf{S}$. Thome escrita por um piloto Portuguez, e mandada do Conde Raymundo de la Torre, gentilhomem veronese traduzida da Lingoa Portugueza para a Italiana, e novamente do Italiano para o Portuguez," from which one learns that the original text in Portuguese was translated into Italian for the sponsor mentioned and then "recently" (recent in 1812, that is) from the Italian into the Portuguese. So much for Tenreiro's Latin original. The edition used by Garfield was a reworked version of the 1812 publication. ${ }^{13}$

The obvious next step was to consult the earlier Italian version. The editor of 1812 mentioned "Ramuzio" and I had encountered a paraphrase (which turned out to be very free) of this account in an Italian book whose author attributed it to the famous collection of travels edited by Giovanni Battista Ramusio. His paraphrase however was an Italian retranslation of the 1812 Portuguese text. ${ }^{14}$ That Italian text, Navigatione da Lisbona all'isola di san Thomè...is part of the very famous Delle Navigationi et Viaggi raccolte da M. Gio. Battista Ramusio (Venice, 1606), 1:114-18v. This was the fifth edition of this great collection, an edition that happened to be available to me. But Ramusio's collection grew with new editions and the date was late, suggesting that this was probably not the original text. Given the importance of a potential date in the 1550 s for "quilombo" and without access to the very rare first and second editions I consulted a microfilm of the third edition of 1563 , which has the account. This third edition is still not the original printed text, only the closest I could come, but I was encouraged that its pagination and 
content are identical with the fifth edition. ${ }^{15}$ In any case, is the printed text of the second edition based on the autograph manuscript of the pilot or is it itself a translation made from that manuscript, as all Portuguese scholars claim? In truth, no one knows, and in this context the question of whether the pilot wrote in Portuguese or in Italian is irrelevant. For the printed second edition is the earliest surviving text and hence in practice the original. All the other editions or paraphrases, whether in Portuguese or in Italian, are derived from it.

However interesting this search for the original text of the pilot's account proved to be, the result of reading this text was negative-no mention of Angolares or "quilombos" whatever. The only relevant information was that only one-third of the island had been deforested and settled by Europeans. ${ }^{16}$ I then conducted a thorough search of all published sources about São Tomé before 1600 in the collection of Brásio, including all references to contemporary sources cited by Garfield. That too did not yield any mention of shipwrecks, quilombos, or Angolares. ${ }^{17}$ Apparently Garfield knew about this absence of any information because he comments that the survivors of the shipwreck remained unknown to the residents of the island for nearly thirty ("History") or at least twenty (History) years, i.e., until 1574, when the capital was suddenly attacked, according to him, by Angolares. ${ }^{18}$ The earliest source about this matter that survives today from that period speaks of expeditions against "the negroes in the bush" in or before $1584 .{ }^{19}$ The next text, written in 1590 by a priest in charge of a parish on São Tomé since 1582 , says that between then and 1590 he accompanied captain Vieira twice to the bush during the "war of Mocambo." ${ }^{20}$ In colonial Portuguese "Mocambo" referred to a slave refugee settlement. These documents indicate that there existed one or more settlements of free Africans in the interior of São Tomé by or shortly during the $1580 \mathrm{~s}$ at the latest. For our purposes it is also relevant to note that the author speaks of "mocambo" and not of "quilombo" to designate them, which strongly suggests that the latter word was not in use at that time.

All this is very well, but the question remains: from where then did Garfield and Tenreiro obtain their information about all of this? The short answer is: from earlier authors. António Almada Negreiros, who is cited by Tenreiro, tells of the shipwreck, the Angolares, and the quilombos. ${ }^{21}$ Negreiros in turn refers to two earlier and famous authorities, R.J. da Cunha Matos and J.J. Lopes de Lima ${ }^{22}$ Both authors are well known to both Garfield and Tenreiro. Indeed, in his dissertation Garfield called Cunha Matos' Corografia "the only real history of S.Thomé in the Portuguese language."23 Both authors have the shipwreck and Angolares story and the attack on the capital in 1574, but only Lopes de Lima mentioned the word "quilombos"24 Lopes de Lima derived his information from Cunha Matos, who collected it during his stay on the island from 1797 to 1814 and when he briefly was its governor in 1816-17..$^{25}$ And it is Cunha Matos who begins to shed light on the origins of the story. He tells us in his Compêndio para. 196: "Diz-se que então naufragara...," "They say that it is then that were shipwrecked..." ${ }^{26}$ In other 
words, the story is an oral tradition which he had perhaps heard while living on the island. Elsewhere, for instance, he cited an oral tradition about the French invasion of 1709 which he gathered in 1797 "from a few old men who had heard it from persons who had lived through it."27

But that is not all. Garfield claimed in his "History" that the major source of the Corografia of Cunha Matos had been an earlier history by Rosário Pinto-and so it turns out to be. ${ }^{28}$ This text from 1734 tells of the shipwreck and the 1574 attack on the capital but this time uses neither the words "Angolar" nor "quilombo." The people in question are called "os negros Angola de Pico" and it is said that they had made their settlement ("aldea," not "quilombo")"on the peak [em Pico] of the mountain." There they multiplied, destroyed many sugar mills, and were on their way to attack the capital when they were defeated and a few of them taken as slaves. ${ }^{29}$

Yet even this is not the earliest written document. In 1971 Castelo Branco discovered an anonymous memoir whose author was in São Tomé between 1712 and 1718. In a passage about the coasts of the island he speaks of a stretch inhabited only by some "negros gentios," ("savage [or heathen] negroes") "who used to do us great damage by nocturnal raids to steal and abduct women which is what they needed most, but today they no longer hurt anyone." These people made and wore barkcloth like the inhabitants of Angola "from where according to tradition [sic] they came in a ship that long ago was wrecked on the coast of these beaches." ${ }^{30}$ These were descendants of Angolans then, but were not yet called Angolares which, like Rosário's text, strongly suggests that that word was not used at that time. And again no sign of "quilombos."

It is a moot point, however, whether this text should be considered to be earlier than Rosário Pinto's, as the latter wrote his relation in his spare time. Both authors were coeval, but Rosário's information is probably earlier. He knew at least something about the "negros Angola" from the time of his youth, say, $c a .1680$.

Thus it is probably wise to consider the information given by both texts as contemporary. While both texts mention the shipwreck they are otherwise quite different and formally independent of each other. However, Rosário Pinto's text alone is at the origin of all later writings. Castelo Branco's essay carefully follows the recording of the tradition about the Angolares from the ca.1712/18 document all the way to Tenreiro's work with the intention of showing that the Angolar tradition is old and respectable. In the concluding section of his article he cited physical anthropological, ethnological, and linguistic data about the present-day Angolares to show that science confirms the oral tradition of a shipwreck from Angola. ${ }^{31}$

What he has in fact shown is how an already existing tradition grew from a few terse sentences about shipwrecked "savage negroes" living in deserted parts of the island to the colorful story found in the latest authors. The "quilombo" detail appears only after 1840, perhaps as a local touch added by Lopes de Lima. Castelo Branco thinks that some of the additional details given by later authors were a genuine part of the continuing oral tradition but were 
not recorded in the terse account of $1712 / 18$, while other details may not be more than conjectures by Cunha Matos. ${ }^{32}$ He does not consider the obvious possibility that the whole tradition began as an etiological story of origin current among the majority population of São Tomé to explain a foreign settlement in their midst and a story that grew after 1700 as this now peaceful group of settlers was in the process of becoming recognized as an ethnic group, the Angolares. In this context it is significant that the last known military action involving this group dates from $1693 .^{33}$

Perhaps there really was a shipwreck sometime before 1574 or 1580 , although it seems unlikely. Be that as may be, in essence the so-called Angolares are the descendants of a maroon community, first mentioned as a refugee settlement "mocambo" existing in the 1580 s, a community that grew as more refugee slaves joined it. The "Angola" designation of this community by $c a .1700$ is unexpected. Most slaves on the island came from Kongo and Benin, although after the mid-sixteenth century a minority came from Angola. The Angolar language, like the general creole on the island, derives mostly from Kongo and Benin influences and exhibits nothing particularly Ambundu, which merely shows that the Angolares were indeed runaway slaves. Perhaps these settlements were called "Angola" because the earliest one consisted of Angolans, perhaps because the word "Angola" had overtones of being free and fierce, or perhaps for some other reason. Who knows in the absence of sources? As to the term "quilombo" to designate such settlements of runaways, that is standard enough in Brazil after about 1700. From that time the term there meant "a hiding place for runaway slaves," an appropriate enough description for the situation on São Tomé. ${ }^{34}$

Most of this journey could have been spared if Garfield and Tenreiro had been both more straightforward in their references and less careless in the descriptions they borrowed, including the term "quilombo." As it is, the sources from São Tomé do not affect accepted accounts about Jaga quilombos in Angola. Secondly, the search once again reminds us that an original document can very well be written in a language other than the usual language of its author despite nineteenth- and even twentieth-century patriotic insinuations that a version in that language must be more "authentic." Thirdly, it was found that the carelessness of recent authors concealed evidence about the elaboration of an oral tradition concerning a certain social group which was transformed during the eighteenth century from a collection of dangerous slave refugees to the ethnic group known as the Angolares.

In addition, and more generally, the search revealed that, despite cosmetic changes, the overall profile of the historiography of São Tomé in 1992 still conforms to the mold cast by Cunha Matos, if not Rosário Pinto in 1734. It suggests in particular that its social and settlement history remains practically unstudied. So while this journey did not upset any existing views about Angolan history, it turned up evidence about something else and hence was not entirely a waste of time. But even if it had-in a merely pedestrian fashion-confirmed already established verities against hitherto unexamined evidence it would not have been a waste of time. 


\section{Notes}

1. Robert Garfield, "A History of São Tomé Island, 1470-1655" (Ph.D., Northwestern University, 1971), 269n59 claims that the term Angolar was common by the end of the sixteenth century for any "wild" black. He maintained this assertion in his A History of São Tomé Island, 1470-1655: the Key to Guinea (San Francisco, 1992), 77n43, only changing "wild" to "found in the forests of S. Tomé." I can find no evidence for this claim, however expressed.

2. Garfield, "History," 56; idem., History, 76-77. The date was changed to 1554 and the words "of course" have been added to the latter work.

3. Beatrix Heintze, Fontes para a história de Angola do século XVII, (Wiesbaden, 1985), 126, also realized that Garfield's passage was the earliest mention of the term.

4. Joseph Miller, Kings and Kinsmen: Early Mbundu States in Angola (Oxford, 1976), 161-75, 194-201. Miller showed how Jaga society had been fashioned out of a motley collection of adventurers and refugees within their kilombo warcamps, starting $c a .1550$.

5. E.G. Ravenstein, The Strange Aventures of Andrew Battell of Leigh (London, 1901).

6. Cf. António Brásio, Monumenta Missionaria Africana: Africa Ocidental, 7 (Lisbon, 1956), 19.

7. Ibid., 6:316.

8. Ibid., 6:284.

9. Francisco Tenreiro, A ilha de São Tomé (Lisbon, 1961), 63, 72.

10. Tenreiro, "Descrição da ilha de St.Tomé no século XVI," Garcia de Orta, 1 (1953), 219-27, written in 1949, completed in 1951. For the quilombos see ibid., 224.

11. Ibid., $227 \mathrm{n} 19$.

12. Ibid., 219n1.

13. Augusto Reis Machado, ed., Viagem de Lisboa à ilha de S.Thomé (Lisbon, n.d.).

14. Tito Omboni, Viaggi nell'Africa Occidentale (Milan, 1845), 257-63. Omboni used the Portuguese translation of 1812 because it was available to him on the island.

15. Apparently this text did not occur in the first edition (1550) and was included in the second (1554), but I could not check this directly. The Italian preface (114) makes clear that the text went to H. Fracastoro, Ramusio's main collaborator-contrary to the claims of the editor of the first Portuguese edition, who mentioned Ramusio himself.

16. Ramusio, Navigationi, $116^{\mathrm{v}-} 117$.

17. A systematic search through the entire Monumenta of Brásio as far as 1699 yielded nothing, nor did any other source in published text editions.

18. Garfield, "History," 56--58; idem., History, 77-79, relying on Tenreiro in both cases. Raimundo José da Cunha Matos, Compêndio histórico das possessóes de Portugal na Africa (Rio de Janeiro, 1963; but written in the 1830s), paragraph 199, cites a document, now lost, from 13 September 1574, allowing the recruitment of condemned murderers or exiles into the armed forces to fight in the bush. The wording of a document of 1591 is very similar. Cf. Brásio, Monumenta, 425-26. Ibid., 461-63 (another document of 1593) links such measures explicitly to threats posed by "rebels and negroes in the bush." None of these documents uses the term "Angolares."

19. The first report in Brásio, Monumenta, 3, 1953, 271-72, mentioning millitary action against negroes in the bush occurs in a short report by the bishop and talks of several military actions against them over an indeterminate period of time before July 1584 .

20. Ibid., 3:389.

21. A. Almada Negreiros, História ethnográphica da Ilha de S. Thomé (Lisbon, [1895]), 59-61, (date of shipwreck, 1540), 293-95, citing Cunha Matos and Lopes de Lima.

22. José Joaquim Lopes de Lima, Ensaio sobre a statistica das posessões Portugueses, $2 / I$ (Lisbon 1844); Cunha Matos, Compêndio; and Corografia histórica das ilhas de São Tomé, Principe, Annobom e Fernão do Pó (Porto, 1842).

23. Garfield, "History," 313-14.

24. Lopes de Lima, Ensaio, Bk. 2, pt. 1, subpart 9. In his preface (xi, xin2), he already told the story and commented that "Angolenses" would be better Portuguese, but Angolares it is. 
25. Cunha Matos, Compêndio, 7.

26. Ibid., 103. See also paragraphs 198 and 199 for the 1574 irruption of the Angolares.

27. Ibid., 127, paragraph 257.

28. Garfield, "History," 314 without giving his evidence for this. That Cunha Matos had access to Rosário Pinto's manuscript is clear from his Compêndio, 127, paragraph 257. Although both Tenreiro and Garfield claim to have used the manuscript, neither used its passage about the Angolares. Cf. Fernando Castelo Branco, "Subsídios para o estudo dos 'angolares' de São Tomé," Studia, 33 (1971), 153n11.

29. António Ambrósio, "Manuel Rosário Pinto," Studia, 30/31 (1970), 231-329, published the complete text of the latter's "Relação." The relevant passage is on 241. Garfield, "History," 316, claimed that the manuscript dates from 1732. Ambrósio, "Manuel Rosário Pinto," 218, proves from the text itself that it was completed in 1734. It is not known when he began to write his relation, except that it was many years earlier. In his dedication he said that he wrote it "during the intervals which my queixas [grievances, sickness, or perhaps duties] allowed me." The author was born in São Tomé in 1666 (206) and, except for his years in the seminary, lived there all his life.

30. Castelo Branco, "Subsídios," 151.

31. Ibid., 156-58. All the "scientific" evidence cited is quite dubious.

32. Ibid., 155.

33. Rosário Pinto, a contemporary, mentioned that the "negros Angola" had taken some slaves from the farms of the settlers to their villages, for which "aldeas" was used, whereupon the govenor sent soldiers to destroy their settlements. Cf. Ambrósio, "Manuel Rosário Pinto," 304.9 .

34. E.g. R. K. Kent, "Palmares, an African State," JAH, 6 (1965), 163, for the first reference (i692), 164 (uncommon in the seventeenth century). 